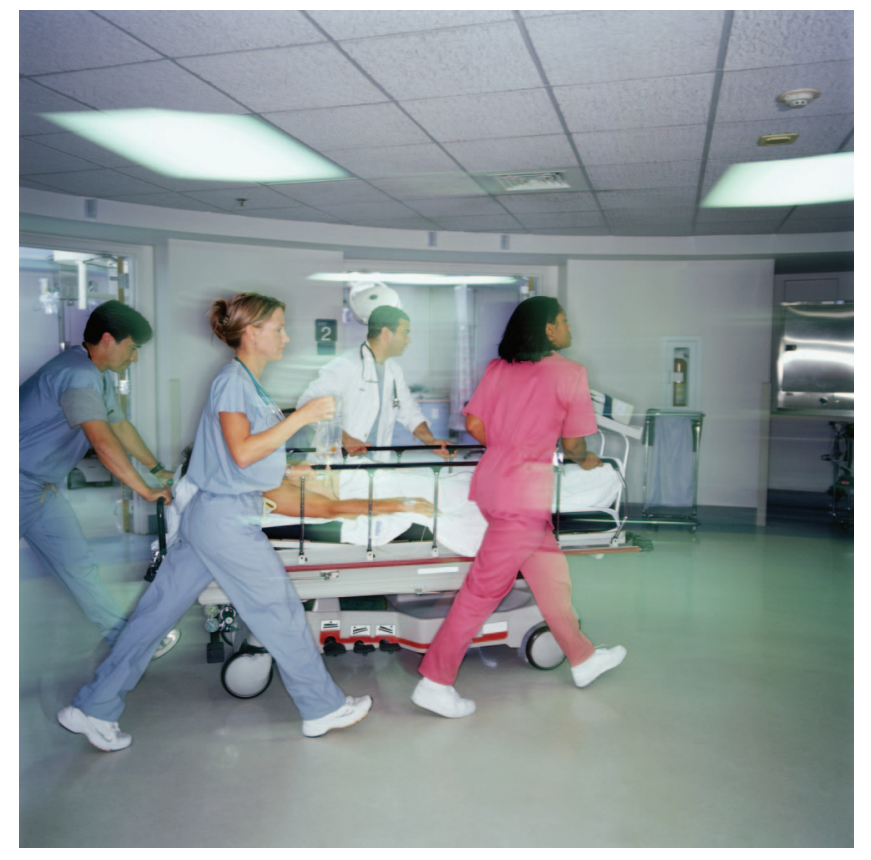

\title{
Amyotrophic Lateral Sclerosis
}

\section{Ethical Challenges}

\section{BY WENDY S. JOHNSTON, MD, FRCP(C) KATELIN HOSKINS, MSN, MBE LEO MCCLUSKEY, MD, MBE}

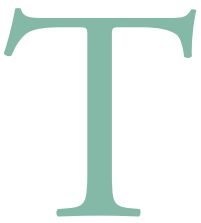

he diagnosis of an incurable disease causing progressive disability unaffected by life-prolonging measures gives rise to many ethical challenges. The core elements of medical ethics can be applied to support decision-making in both common and unusual situations. In this fictional case, ethical dilemmas from several actual cases have been combined to illustrate ethical challenges that may be encountered in the care of a patient with amyotrophic lateral sclerosis (ALS).

A 42-year-old man presents to the emergency room with depressed level of consciousness and arm weakness. $\mathrm{He}$ is intubated with a presumed stroke. The stroke team notes atrophy of the hand and arm muscles, generalized hyperreflexia, and bilateral Babinski responses, and refers the patient to the general neurology service.

The patient's wife, Anne Smith, reports that her husband Glen has suffered weakness of the hands and then arms gradually over the last year. Three months ago, he consulted a neurologist, who performed numerous investigations, then told Glen he had ALS or Lou Gehrig's disease. The neurologist told him that it was an incur-

From the Department of Medicine (Neurology) (W.S.J.), University of Alberta, Edmonton, Canada; and Department of Neurology (K.H., L.M.), University of Pennsylvania, Philadelphia.

Address correspondence and reprint requests to Wendy S. Johnston, 2E3.17 Walter Mackenzie Health Sciences Centre, 8440112 St. Edmonton, Alberta, Canada, T6G 2B7; wendy.johnston@ualberta.ca

Author disclosures are provided at the end of the article.

Neurology ${ }^{\circledR}$ Clinical Practice 2011;76 (Suppl 2):S1-S5 able disease that caused gradual paralysis and resulted in death from respiratory failure in 18 months to 2 years. He gave Glen a brochure for the ALS Association. Anne had not attended these appointments; Glen told her much later that he had been given a "death sentence." When Anne called to make a follow-up appointment, she was told that a referral to the ALS clinic was pending. Since the diagnosis, Glen has seemed increasingly tired. He has been napping after work, and for the past week he has had headaches in the mornings. Anne had assumed Glen was depressed by the diagnosis and became alarmed only when he could not be roused this morning.

ALS ethics begins with breaking the news. Physicians should break the news in a manner that invites confidence both in the veracity of the diagnosis but also in his or her ability to manage the illness and support the patient and family. Too often, patients with ALS feel that the diagnosis is imparted in an impersonal or dismissive fashion. ${ }^{1}$ The delivery of bad news should take place in an appropriate setting after thoughtful preparation. The patient and family should be invited to share their understanding of the process so far and their thoughts on the potential diagnosis. Next, the physician can impart knowledge of the diagnosis and some of its implications. Hard timelines on prognosis should be avoided, and empathetic listening and emotional support should be offered throughout. The physician should summarize the information and formulate a plan. ${ }^{2} \mathrm{He}$ or she must utilize clear language and avoid "neuro-jargon," leaving the patient with a sense of direction and support. Patients with ALS report experiences with breaking the news that lack many of the recommended elements. ${ }^{1}$ 
"Physicians cannot abandon patients, even if faced with unacceptable behavior or requests"

Glen Smith is now alert and communicates by printing, though with difficulty. He demands immediate extubation. His wife is opposed, stating that she might invoke power of attorney because "Glen isn't himself-he isn't capable of making a decision." She requests another opinion and is hopeful that a curable condition will be discovered.

With Glen alert and communicating effectively, Anne's intent to invoke medical power of attorney may not seem clinically justified. However, the care team should explore Anne's observation that her husband is "not himself." Respiratory failure alone, with compromise of gas exchange, can lead to encephalopathy, clouding judgment. With the respiratory failure controlled by mechanical ventilation, Glen can be assumed to be at his baseline cognitive status. Emerging evidence of cognitive dysfunction in ALS suggests that up to half of patients with ALS may have some degree of impairment when detailed neurocognitive tests are administered. Frank dementia is still rare, but executive function, including decisionmaking capacity and language, may be affected. The extent to which this dysfunction compromises capacity for medical decisions has not been determined, but capacity must be seen as a threshold concept. ${ }^{3}$ In Glen's case, a screening test of cognitive function sensitive to frontal measures might further justify clinical competency assessments.

Cognitive screening tests show no sign of frontal dysfunction. After the psychiatry team assesses Glen as competent, Glen, Anne, and the care team reach a compromise. Glen agrees to be weaned to noninvasive ventilation (NIV). After the successful wean, repeat investigations confirm the ALS diagnosis. Glen now reveals more from his original breaking-the-news conversation: when he was told the diagnosis, he had asked the neurologist about assisted suicide. The neurologist had said "he couldn't help him with that" and abruptly ended the visit. No follow-up was offered; Glen declined the scheduled appointment at the ALS clinic.

Physicians cannot abandon patients, even if faced with unacceptable behavior or requests. The moral requirement to ensure that appropriate medical care is continued and the fiduciary responsibility to the patient persist even when a request or action violates a physician's own values. Referral to another physician may technically fulfill such obligations, but in the setting of a new and life-threatening diagnosis, greater effort to understand the motivation behind such requests or actions is a better therapeutic strategy. Interest in assisted suicide and euthanasia is high in patients with ALS, reflecting fear of suffering at end of life, as well as loss of autonomy and concern about burdening loved ones. ${ }^{4}$ Patients with ALS have been prominent participants in assisted suicide, and have been featured in media coverage of the legal debate. Questions about hastening death may not reflect a strong or sustained desire to pursue this end, but may be the first foray into end-of-life questions, and a desire to be assured of care from diagnosis to death. A query about hastened death should prompt a discussion of disease progression that includes the spectrum of medical care from the choice of natural death while using hospice and palliative care for medical management of symptoms to a decision to prolong life using elective tracheostomy for long-term mechanical ventilation. Glen's query had opened the door to a discussion about his beliefs and values in these possibilities. ${ }^{5}$

During the current admission, Glen is given further information about ALS, offered riluzole, and referred to the multidisciplinary ALS clinic, which he refuses. He does complete a personal directive in which he specifically declines intubation or enteral feeding. He agrees to follow-up in the general neurology clinic. Glen is discharged to home with home care and an outpatient appointment in 1 month.

Three weeks later, Anne Smith urgently calls the general neurology office. Glen is in Europe for a "cutting edge stem cell treatment that will reverse his ALS symptoms." The European clinic has offered to harvest Glen's stem cells to be administered at home by their own provider. Anne explains that their debt from financing the treatment and travel is considerable. Anne is uncertain that the treatment will work, but Glen and other family members are hopeful. Would the neurologist administer the stem cells?

With no curative therapy offered by conventional medicine, patients with ALS may seek potentially costly complementary and alternative medicine (CAMs). Patients and families may discuss their desire for these treatments with their medical practitioners from various motives, seeking advice regarding the safety and scientific basis of proposed therapies, sanction for their use, assistance to obtain funding, or aid in the delivery of the treatment, as Anne is requesting. It is good medical practice to be informed of CAMs because of potential toxicity and impact on health. ${ }^{3}$ However, physicians are not obliged to engage in discussions about or aid in the delivery of unproven therapies. ${ }^{4}$ Collaborating with a social worker, physicians should advise patients and families of the costs not covered by medical insurance. A compassionate response may be to gently refuse to administer the stem cells and address concern for 
false hope. The physician should also arrange a social work referral to review options to manage the family's financial burden and follow Glen medically on his return. From a practical perspective, the physician should advise on the safety of traveling with NIV.

Glen does not attend the scheduled outpatient appointment and does not return calls to reschedule. Now he is back in the emergency room with uncontrolled symptoms, including breathlessness. In the weeks following the Smiths' return from Europe, Glen has increasingly resorted to using the NIV for dyspnea control. He has lost weight. His family begs him to revoke his personal directive and accept life-sustaining therapies "to give time for the stem cells to work." Anne reminds the emergency room staff that she has medical power of attorney, which she will invoke should he continue to refuse intubation and become obtunded.

The Smiths' pattern of accessing the medical system only during times of crisis forces more difficult medical and ethical decisions. Despite discussions about medical interventions and directives during the prior admission, Glen and his family are unprepared for his death. As well as facing the wrenching prospect of personal loss, there may also be unresolved financial and legal implications. This is a palliative care emergency, requiring a coordinated effort to relieve the physical and emotional suffering of Glen and his family, as well as to reduce the psychosocial obstacles to stabilize the family. While the specific legal and ethical issues may require a clinical ethicist's assistance, identifying the underlying motivations of the patient and his family may obviate the need for a formal ethics review. Glen needs to be assured that he can accept life-sustaining therapies such as short-term or long-term mechanical ventilation (LTV) and placement of a feeding tube, knowing that he has the legal and ethical right to withdraw from their use in the future, and that he may do so without suffering. ${ }^{4}$ Respecting Anne's desire to keep Glen alive at any costs, the team can nonetheless remind her that, as the surrogate decision-maker, she needs to represent Glen's wishes, not her own. ${ }^{5}$

\section{Ethics in ALS}

- Avoid being impersonal or dismissive when breaking news of the diagnosis.

- Do not abandon patients, even if faced with unacceptable behavior or requests.

- Physicians are not obliged to discuss or aid in the delivery of unproven therapies.

- Surrogate decision-makers must represent the patient's wishes, not their own.

- Provide supportive intervention, not confrontation, if faced with ethically questionable actions.
Assured by the medical team that he can withdraw in the future, Glen reluctantly accedes to his family's wishes. Nine months later, he is now on long-term ventilation via tracheostomy at home. The disability has progressed such that he is dependent on family for all care, and is fed through a gastrostomy tube. Now quadriplegic, but with speech intact, he reveals that he watched his father die of ALS, unable to speak or move before dying. He feels guilty that his children may be at risk for ALS. In addition to his emotional distress, he is suffering pain in his back and joints, unrelieved by repositioning or massage. Although ineligible for home hospice because of LTV, he is followed by the hospital palliative care consult service. Despite their support, Anne refuses to administer the prescribed narcotics, because she is afraid opioids will hasten Glen's death. Fear of suffering the same fate as his father prompted him to ask about assisted suicide when diagnosed; he now feels his worst fears are realized.

Faced with such evident suffering, the care team may become judgmental of Anne's actions. The medical team must realize that supporting a patient with ALS at home, especially on LTV, can impose significant physical, emotional, and financial burdens on a family. Some patients and families manage to thrive, while others become socially isolated. The emotional, physical, and financial demands can drain the resources of the caregivers, negatively affecting their own health and quality of life. Alternatives to living at home may not be economically possible or socially acceptable. Caregivers may feel that their actions alone determine whether their loved one will live or die. Identifying ethically questionable actions, for example withholding pain medication, should prompt supportive intervention rather than confrontation. Efforts to educate about the principle of double effect, ${ }^{6}$ respect for patient autonomy, and the medical realities of pain management (e.g., opioid respiratory depression not at issue with mechanical ventilation) can moderate caregivers' fears and concerns. A family-centered solution should be attempted but if the interventions are unsuccessful, a physician must ultimately enact his or her fiduciary responsibility to advocate for better treatment of the vulnerable patient. ${ }^{5}$

A family conference reveals that Anne feels more comfortable with professional caregivers assessing and treating Glen's pain. Glen's family believes that they can no longer safely care for him at home. Now in a longterm care facility for the past months, followed by the outpatient palliative care program, Glen feels his pain and mood are improved, but he still fears losing the ability to communicate. His personal directive states that he wishes to be withdrawn from the ventilator before he must rely on others to interpret his nonverbal 
cues. He has sent word through his wife that he would like to plan the withdrawal in the next few weeks. His family now supports his decision. However, the facility is unwilling to allow the withdrawal because the Smiths have not paid the last 2 months' invoice.

The intrusion of the commercial aspects of medical care, particularly at end of life, is an affront to basic moral principles of medicine. In the end, the welfare of the patient is the overriding concern. Direct discussion with the medical director may lead to a compromise. There may be legal concerns or medical uncertainty masked by a request for payment. Instead of rebuking the denial, Glen's care team should attempt to seek a better understanding of the situation.

The palliative care social worker finds that the longterm care facility has never participated in a withdrawal but is willing to transfer the patient back to the hospital. They settle for a token payment for the outstanding balance owed. Glen is admitted, says his goodbyes to his family, and is withdrawn from the ventilator under palliative sedation.

While the care of patients with ALS is not necessarily fraught with all elements of this case study, the lost autonomy, grief, and suffering that accompany this disease may have subtler implications for decision-making. The physician must realize that each new symptom presents a potential ethical juncture. Resources are available that reflect both the evidence $^{3}$ as well as expert consensus. ${ }^{5,7}$ By breaking the news in a compassionate, truthful manner, establishing a trusting relationship, addressing false hope, and continually probing patients' values, physicians can more effectively navigate the inevitable ethical challenges of ALS disease progression.

\section{DISCLOSURE}

Dr. Johnston receives research support from the Canadian Institutes of Health Research. Dr. McCluskey and K. Hoskins report no disclosures.

Received October 14, 2010. Accepted in final form December 23, 2010.

\section{REFERENCES}

1. McCluskey L, Casarett D, Siderowf A. Breaking the news: a survey of ALS patients and their caregivers. Amyotroph Lateral Scler Other Motor Neuron Disord 2004;5:131135.

2. Buckman R. How to Break Bad News: A Guide to Health Care Professionals. Baltimore, MD: Johns Hopkins University Press; 1992.

3. Miller RG, Jackson CE, Kasarskis EJ, et al. Quality Standards Subcommittee of the American Academy of Neurology: Practice Parameter update: the care of the patient with amyotrophic lateral sclerosis: multidisciplinary care, symptom management, and cognitive/behavioral strategies. Neurology 2009;73:1227-1233.

4. Maessen M, Veldink JH, Van den Berg LH, et al, Requests for euthanasia: origin of suffering in ALS, heart failure, and cancer patients. J Neurol 2010;257:1192-1198.

5. McCluskey L. Amyotrophic lateral sclerosis: ethical issues from diagnosis to end of life. Neurorehabilitation 2007;22: 463-472.

6. Sulmasy DP. Commentary: double effect: intention is the solution, not the problem. J Law Med Ethics 2000;28:2629.0

7. Mitsumoto H, Bromberg M, Johnston W, et al. Promoting excellence in end-of-life care in ALS. Amyotroph Lateral Scler Other Motor Neuron Disord 2005;6:145-154 (see also Completing the Continuum of ALS Care: A Consensus Document: http://www.promotingexcellence.org). 


\section{If you liked this article, you may be interested in ...}

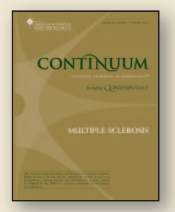

\section{Continuum}

Myasthenic Disorders and ALS issue. February 2009; www.aan.com/go/elibrary/continuum

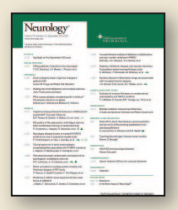

\section{Neurology}

C. Armon. Is the lithium-for-ALS genie back in the bottle?: Not quite. August 17, 2010; www.neurology.org

D. Bäumer et al. Juvenile ALS with basophilic inclusions is a FUS proteinopathy with FUS mutations. August 17, 2010; www.neurology.org

A. Chiò et al. Lithium carbonate in amyotrophic lateral sclerosis: Lack of efficacy in a dose-finding trial. August 17, 2010; www.neurology.org

D.G. Munoz. FUS mutations in sporadic juvenile ALS: Another step toward understanding ALS pathogenesis. August 17, 2010; www.neurology.org

S. Waibel et al. Novel missense and truncating mutations in FUS/TLS in familial ALS. August 31, 2010; www.neurology.org

$\mathrm{J}$. Yan et al. Frameshift and novel mutations in FUS in familial amyotrophic lateral sclerosis and ALS/dementia. August 31, 2010; www.neurology.org

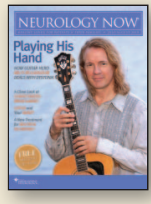

\section{Neurology Now}

Kierstin Wesolowski. Evaluation of treatments for muscle cramps. March/April 2010; www.neurologynow.com

Annie Levy. Pictures of You. September/October 2010; www.neurologynow.com Jamie Talan. The CEO of ALS research. September/October 2010; www.neurologynow.com Jamie Talan. Your voice is my command. September/October 2010; www.neurologynow.com

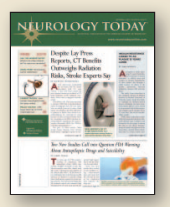

\section{Neurology Today}

Kurt Samson. AAN panel updates guidelines on ALS treatment and management. October 15, 2009; www.neurotodayonline.com.

Jamie Talan. New data: Lithium found ineffective for ALS. May 6, 2010; www.neurotodayonline.com.

Richard Robinson. New ALS drug shows dose-dependent efficacy in phase 2 trial. July 1, 2010; www.neurotodayonline.com.

Jamie Talan. Does concussion cause motor neuron disease?: The question stirs debate. September 16, 2010; www.neurotodayonline.com. 


\title{
Neurology
}

\author{
Amyotrophic Lateral Sclerosis: Ethical Challenges \\ Wendy S. Johnston, Katelin Hoskins and Leo McCluskey \\ Neurology 2011;76;S1-S5 \\ DOI 10.1212/WNL.0b013e31820d57ee
}

This information is current as of February 14, 2011

\section{Updated Information \& Services}

References

Citations

Subspecialty Collections

Permissions \& Licensing

Reprints including high resolution figures, can be found at: http://n.neurology.org/content/76/7_Supplement_2/S1.full

This article cites 6 articles, 1 of which you can access for free at: http://n.neurology.org/content/76/7_Supplement_2/S1.full\#ref-list-1

This article has been cited by 1 HighWire-hosted articles: http://n.neurology.org/content/76/7_Supplement_2/S1.full\#\#otherarticl es

This article, along with others on similar topics, appears in the following collection(s):

Amyotrophic lateral sclerosis

http://n.neurology.org/cgi/collection/amyotrophic_lateral_sclerosis_ Palliative care

http://n.neurology.org/cgi/collection/palliative_care

Professional conduct and ethics

http://n.neurology.org/cgi/collection/professional_conduct_and_ethics

Information about reproducing this article in parts (figures,tables) or in its entirety can be found online at:

http://www.neurology.org/about/about_the_journal\#permissions

Information about ordering reprints can be found online:

http://n.neurology.org/subscribers/advertise

Neurology ${ }^{\circledR}$ is the official journal of the American Academy of Neurology. Published continuously since 1951, it is now a weekly with 48 issues per year. Copyright Copyright $@ 2011$ by AAN Enterprises, Inc.. All rights reserved. Print ISSN: 0028-3878. Online ISSN: 1526-632X.

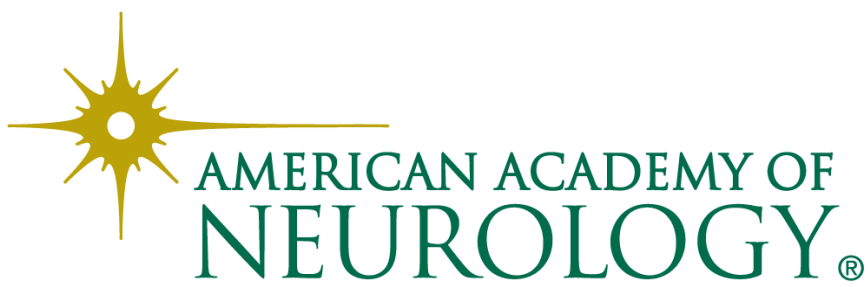

